\title{
Acceleration of the decomposition of Sicilian lemon leaves as an auxiliary measure in the control of citrus black spot
}

\author{
José A.M. Bellotte ${ }^{1}$, Kátia C. Kupper ${ }^{2}$, Davi Rinaldo ${ }^{1}$, Andressa de Souza ${ }^{1}$, Fernanda D. Pereira ${ }^{1}$ \& Antonio \\ de Goes $^{1}$
}

${ }^{1}$ Departamento de Fitossanidade, Universidade Estadual Paulista, Faculdade de Ciências Agrárias e Veterinárias, 14884-900, Jaboticabal, SP, Brazil; ${ }^{2}$ Instituto Agronômico de Campinas, Centro de Citricultura, 13490-970, Cordeirópolis, SP, Brazil

Author for correspondence: Antonio de Goes, e-mail: agoes@fcav.unesp.br

\begin{abstract}
In the current study, various treatments were used in the acceleration of decomposition in Sicilian lemon leaves as an auxiliary measure to control citrus black spot. The treatments tested were: 1) urea $(12.5 \mathrm{~g} / \mathrm{L}) ; 2)$ calcium nitrate $(12.5 \mathrm{~g} / \mathrm{L}) ; 3)$ dolomitic limestone $(2 \mathrm{t} / \mathrm{ha}) ; 4)$ Embiotic ${ }^{\circledR}$ (commercial composting accelerator - 1\% of the activated product); 5) Soil-Set ${ }^{\circledR}+$ Compostaid ${ }^{\circledR}(0.75 \mathrm{~mL} / \mathrm{L}$ $+0.75 \mathrm{~g} / \mathrm{L}$; and 6) control. Treatments $1,2,4$, and 5 were applied in solution under the plant's crowns (800 L/ha), while dolomitic limestone was applied to only one side of the plant using a drop spreader. The most efficient treatment in reducing leaf weight was with urea, calcium nitrate and Soil-Set $\AA+$ Compostaid $\AA$. In relation to cellulose, Embiotic $\AA$ and Soil-Set $\AA+$ Compostaid $\AA$ reduced the same content showing a high efficiency in the decomposition rate of the lemon leaves. As for the dehydrogenase activity, there was an increase in the first and second evaluations, followed by a reduction in the second and third observations, amounting to $9.90 \%$ for dolomitic limestone, and $72.41 \%$ for the control. The results showed the viability of accelerating decomposition of citrus leaves fallen on the soil as a supplementary control measure for Guignardia citricarpa.
\end{abstract}

Keywords: Guignardia citricarpa, Phyllosticta citricarpa, Citrus limo, Cultural control.

\section{RESUMO}

Aceleração da decomposição de folhas de limoeiro 'Siciliano' como medida auxiliar no controle da mancha preta dos frutos cítricos

Nesse estudo foram avaliados tratamentos quanto à aceleração da decomposição de folhas de limoeiro 'Siciliano ', como medida auxiliar no controle da mancha preta dos citros. Os tratamentos testados foram: 1) uréia $(12,5 \mathrm{~g} / \mathrm{L}) ; 2)$ nitrato de cálcio (12,5 g/L); 3$)$ calcário dolomítico $(2 \mathrm{t} / \mathrm{ha}) ; 4)$ Embiotic ${ }^{\circledR}$ (acelerador de compostagem - 1\% do produto ativado); 5) Soil-Set $(\AA+\operatorname{Compostaid} \AA(0,75$ $\mathrm{mL} / \mathrm{L}+0,75 \mathrm{~g} / \mathrm{L})$ e 6 ) Testemunha. Os tratamentos $1,2,4$ e 5 foram aplicados em solução sob a copa das plantas (800 L/ha), enquanto o calcário o foi com um distribuidor, direcionando o produto para um lado da planta. Os tratamentos mais eficientes na redução do peso das folhas foram uréia, nitrato de cálcio e Soil-Set $\AA+$ Compostaid ${ }^{\circledR}$. Quanto à cellulose, Embiotic $\AA$ e Soil-Set $\AA+$ Compostaid $\AA$ reduziram o conteúdo da mesma, mostrando alta eficiência na taxa de decomposição das folhas. Quanto à atividade da dehydrogenase, houve aumento da mesma entre a primeira e segunda avaliações, seguido de redução entre a segunda e terceira avaliações, sendo essas entre $9,90 \%$, no caso do calcário dolomítico e $72,41 \%$, na testemunha. Os resultados demonstraram viabilidade da aceleração da decomposição das folhas cítricas caídas no solo como medida suplementar ao controle de Guignardia citricarpa.

Palavras-chave: Guignardia citricarpa, Phyllosticta citricarpa, Citrus limon, Controle cultural.

\section{INTRODUCTION}

The state of Sao Paulo is responsible for $97 \%$ of Brazilian orange juice exports, with the largest orangegrowing area in the world, holding about 200 million orange plants over 13,000 properties. This area comprises about 690 thousand hectares and is distributed throughout almost the whole state of Sao Paulo; it is complemented by citrus areas located in the Triangulo Mineiro region, in the state of Minas Gerais, Brazil. In the 2007/2008 harvest, the sector was responsible for the production of 368 million boxes of oranges weighing in at 40.8 kilograms each.
A great benefit of this activity is that it generates approximately 400 thousand jobs, contributing significantly to agricultural development in Sao Paulo (Secretaria de Estado de Agricultura, Pecuária e Abastecimento de São Paulo, 2008). On the other hand, in spite of the citrus industry's strength in Brazil, the spatial continuity of citrus properties in the regions, and the low genetic variability found in the citrus orchards, are conditions that favor the occurrence of pests and diseases (Spósito, 2003).

Currently, citrus black spot (CBS) is among the most serious fungal diseases in Sao Paulo, caused by the fungus G. citricarpa, affecting leaves, branches and mainly fruits, which lose value on the fresh fruit market. This disease, in its 
most severe state, can cause significant premature fruit drop, disrupting plant productivity. Citrus Black Spot is derived from two sources of inoculum produced by G. citricarpa: conidia and ascospores (Kotzé, 1988). Conidia, which are formed in the pycnidia in branches, leaves, and especially in fruits, are among the inoculum sources responsible for the dispersal of the pathogen. When mature, they emerge from the ostiole immersed in a mucilaginous substance, which, when in contact with water, dissolves and releases conidia that are carried in suspension to a nearby susceptible organ, where new infections may develop (Nozaki, 2007).

As well as conidia, ascospores are also of high epidemiological importance. They are produced in decomposed leaves found in the soil. Pseudothecium is formed on the brightest side of these leaves due to positive phototropism. Several bitunicated asci are formed inside the pseudothecium. They are cylindrical-clavated and have eight ascospores each. Ascospores mature between 40 and 180 days from defoliation, depending on the strong influence of environmental factors and handling characteristics (Kotzé, 1988). Control of the pathogens is based on fungicides. Therefore, it is believed that measures leading to the acceleration of decomposition of the fallen leaves under the citrus plant's crowns could inhibit the formation of pseudothecium and, consequently, reduce the source of inoculum presented by the ascospores.

Sources conclude that there are several compounds present in the acceleration of plant material decomposition. Nitrogen fertilizers are among them, since these favor microorganisms with cellulolytic activity (Zaman et al., 1999). Also, the use of dolomitic limestone and the resulting increase in $\mathrm{pH}$ values aids the activity of decomposers. Other products derived from a mixture of microorganisms that could directly act in the decomposition of plant material, like Embiotic ${ }^{\circledR}$, can also be mentioned. Additionally, other commercial products like Soil-Set ${ }^{\circledR}$ and Compostaid $\AA$ are made for this very purpose (http://www.alltech.dk/ About/agrproducts.cfm). The objective of this study was to evaluate the accelerated decomposition effects of Sicilian lemon leaves which land under the plants' crowns and, in turn, promote the reduction of inoculum sources which contribute to disease control.

\section{MATERIAL AND METHODS}

This experiment was held on commercial property within the city of Rio Claro, in the state of Sao Paulo (geographic coordinates, $22^{\circ} 25^{\prime}$ South, $47^{\circ} 18^{\prime}$ West). This property has a history of high incidences of citrus black spot. The plants used in this study were 10 year old Sicilian lemon trees [Citrus limon (L) Burm. F.], grafted on Rangpur lime (Citrus limonia Osbeck).

The treatments and doses used were: 1) urea (12.5 $\mathrm{g} /$ liter); 2) calcium nitrate (12.5 g/liter); 3) dolomitic limestone (2t/ha); 4) Embiotic $\AA$, a commercial composting accelerator ( $1 \%$ of activated product); 5) combination of two commercial products, Soil-Set ${ }^{\circledR}+$ Compostaid ${ }^{\circledR}$ $(0.75 \mathrm{~mL} / \mathrm{L}$ and $0.75 \mathrm{~g} / \mathrm{L}$, respectively); and 6$)$ control. The statistical design used was in completely random blocks, with six treatments and four replications, using ten plants per plot.

The products were applied under the plant's crowns using a sprayer equipped with a herbicide application bar. One Teejet ${ }^{\mathbb{R}}$ and six 8004 nozzles positioned at the end of the bar was used to allow maximum coverage. The sprayer was calibrated to have an application rate of 800 $\mathrm{L} / \mathrm{ha}$. The limestone (in each application) was used in haul under the plant's crowns, seeking similar coverage to that obtained by the spray bar. For this, a trawling tractor was used, directing the product to a specific part of the plant each time it passed. To facilitate evaluations, leaves under the plant's crowns were collected at the beginning of the experiments and stored in boxes made of galvanized metal screen. For each treatment plot six samples were collected from the central plants. Each box corresponded to a sampling period. For analysis, one box with six different dates was used, with corresponding times of each treatment application before spraying. These boxes were taken to the Biochemistry Laboratory of the Department of Technology at FCAV/UNESP in the city of Jaboticabal, Sao Paulo. The evaluations were: i. dry mass sampling on $10 / 29 / 04$, $11 / 12 / 04,12 / 10 / 04$, and $01 / 08 / 05$; ii. cellulose contents and iii. dehydrogenase enzymatic activity that was determined on 10/29/04, 11/26/04, and 12/23/04.

The control of insects and mites, as well as fertilization and other cultural treatments, was done according to the commercial standards predetermined on the property. Since the objective of this assay was to determine the auxiliary effect of the decomposition of leaves in the control of CBS, fungicide spraying also followed the recommended standards and was done twice (copper oxychloride, 90g a.i./ 100L), on 10/15/04 and 11/18/04, and complemented with an application of the systemic fungicide methyl tiophanate, $37.5 \mathrm{~g}$ a.i./100L) on 12/20/04.

The final evaluations were conducted on $05 / 28 / 05$, when values were assigned, according to a fruit diagrammatic scale (Spósito, 2003), in order to quantify the severity of the disease in the experimental area. The values of Sposito's scale range from 0 (no symptom) to 6 (maximum severity). For analysis, six central plants from each plot were used, totaling 100 fruits per plant. Later, the disease index (DI) was determined using the McKinney index formula (1923) as shown:

$$
I D=\frac{\sum_{k=1}^{K} F_{k} x_{k}}{n x_{k}}
$$

where $\mathrm{F}_{\mathrm{k}=}$ number of fruits with certain degree of infection $\mathrm{x}_{\mathrm{k}}, \mathrm{k}=0,1, \ldots, \mathrm{K}$, in the plot; $\mathrm{n}$ equals the number of fruits evaluated; $x_{k}$ equals the highest number from the adopted scale. To evaluate the mean normality and homogeneity variance, the infection intensity index (I) was determined. It 
was expressed using $\mathrm{I}=\mathrm{sen}^{2} \mathrm{w}$, whose angular transformation $\mathrm{W}=\operatorname{arcsen} \sqrt{\mathrm{I}}$ was determined by statistical procedures as proposed by Czermainski (1999).

\section{RESULTS AND DISCUSSION}

Regarding the acceleration of Sicilian lemon leaves' decomposition, evaluated by determining the average leaf weight, no statistical difference among the treatments was observed in the third preview evaluation (Figure 1). However, in the last evaluation, on 01/08/05 it was observed that Soil-Set ${ }^{\circledR}+$ Compostaid $\AA$ had reduced the average weight of dry matter (Duncan, $P \leq 0.05$ ). Nitrogen compounds showed average behavior, while dolomitic limestone and Embiotic ${ }^{\circledR}$ products were similar to the control (Table 1); the decomposition rates of urea and calcium nitrate were $25.84 \%$, $48.15 \%$, respectively, and with the Soil-Set $\AA+$ Compostaid $\AA$ solution it was $49.75 \%$. Soil-Set ${ }^{\circledR}$ and Compostaid $₫$ consist of a combination of products commercially advocated to enhance organic residue degradation. Among the constituents are bacteria mixtures, enzymes and basic micronutrients (http://www.alltech.dk/About/agrproducts.cfm).

In view of this, it can be proven that when time and availability of substrate and environmental factors are favorable to the activity of the bacteria present the results obtained are consistent. Furthermore, it is possible that the additional nutrient supplements provided by the Soil-Set ${ }^{\circledR}$ and Compostaid $\AA$ solution offer favorable conditions for the development of pre-existing microbial flora, as well as those available through application. The effect of enzymes in the composition of products also contributed to the acceleration of decomposition.
In comparison, calcium nitrate was more effective in accelerating decomposition in relation to the urea. It is recognized that, although both products contain the essential basic nitrogen compounds, it is possible that the urea, by promoting change in average $\mathrm{pH}$ levels, usually raising them, can affect the microorganism activity. In addition, the possible importance of the calcium present in the formulation of the nitrate cannot be underestimated, since it shows how important elements in the microbial metabolism are. Furthermore, dolomitic limestone provides calcium and magnesium, which are essential elements for plant development, neutralizes soil acidity and reduces the solubility of manganese, iron and aluminum, which are toxic to plants when in large quantities. Dolomitic limestone also accelerates the decomposition of plant waste, releasing nitrogen and phosphorus, which is beneficial to plant growth (http://www.mibasa.com.br/calcario_dolom.htm).

Overall, these responses reflect the most substantial contribution of soil microorganisms, including the existence of microorganisms in rhizosphere and in rhizoplane. In such cases, the low efficiency observed in the use of limestone is most probably related to the short period of time allowed for the limestone to alter the physical and chemical characteristics of the soil, thus providing good conditions for the expression of existing biological microflora. Moreover, when compared with the efficiency of dolomitic limestone and the other compounds used, it is possible that, since it contains elements less readily available to the microflora components, it will not have provided the good conditions generated by the other products, therefore reflecting the rate of lemon tree leaves' decomposition evaluated.

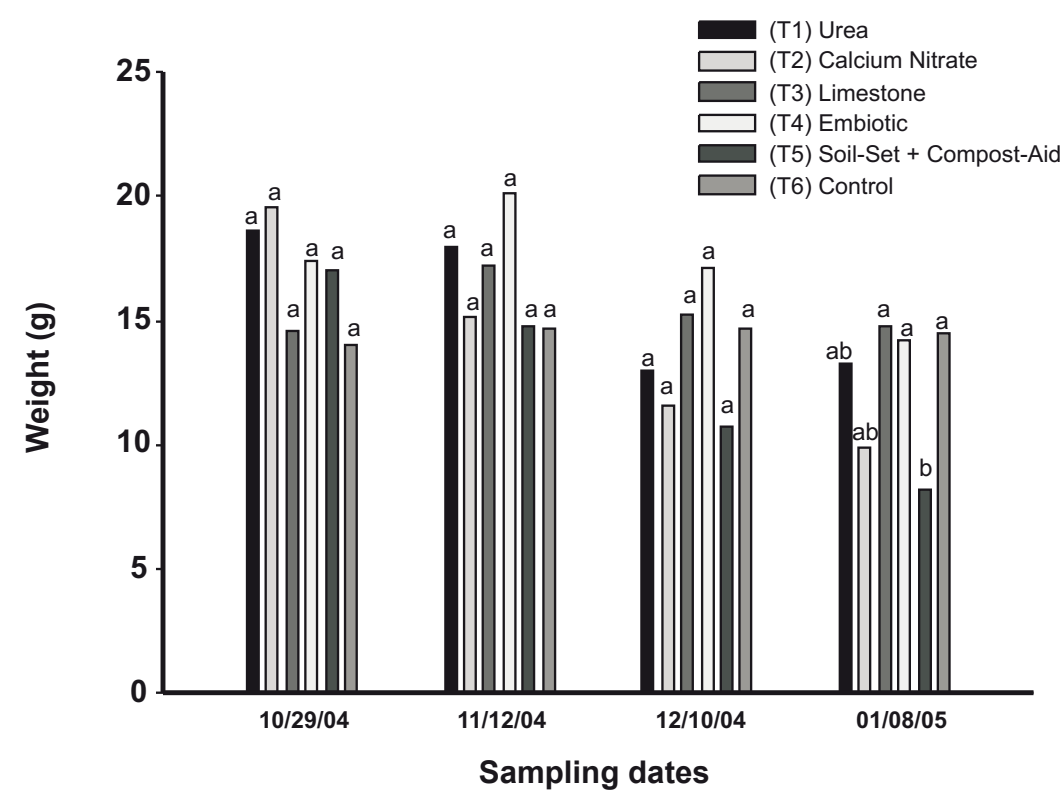

FIGURE 1 - Variation of dry matter weight from Sicilian lemon leaves collected from under the plant's crowns, before treatments focusing on the acceleration of decomposition. Rio Claro-SP, Brazil, 2004/2005. 
TABLE 1 - Weight (in g) of the dry matter weight of Sicilian lemon leaves after treatments for decomposition acceleration. Rio Claro/SP, Brazil, 2004-2005

\begin{tabular}{lc}
\hline \hline Treatments & Weight (g) \\
\hline (T1) Urea $^{2}$ & $13.250 \mathrm{ab}^{1,2}$ \\
(T2) Calcium Nitrate & $9.922 \mathrm{ab}$ \\
(T3) Limestone $\left.^{(}\right)$ & $14.727 \mathrm{~b}$ \\
(T4) Embiotic $^{(}$ & $14.195 \mathrm{~b}$ \\
(T5) Soil-Set $^{\circledR}+$ Compostaid $^{\circledR}$ & $8.175 \mathrm{a}$ \\
(T6) Control $^{(T) .480 ~ b}$
\end{tabular}

${ }^{1}$ Data corresponding to dry matter weight determined between the $1^{\text {st }}$ and $6^{\text {th }}$ sampling, carried out on $29 / 10 / 2004$ and $08 / 01 / 2005$, respectively. ${ }^{2}$ Averages followed by the same letter did not differ statistically (Duncan, $P \geq 0.05$ ).

As for Embiotic ${ }^{\circledR}$, it is necessary to establish it in a place where it can spread and promote new population equilibrium among the microorganisms. In relation to cellulose, one of the most important components of the plant cell wall, the treatments represented by Embiotic ${ }^{\circledR}$ and Soil-Set ${ }^{\circledR}+$ Compostaid $^{\circledR}$ reduced the content, showing a high effect in the decomposition rate of fallen lemon leaves (Table 2). Possibly, the response is due to the presence of microorganisms present in the leaves, which produce cellulolytic enzymes that hydrolyse the cellulose and derivates with consequent biodegradation of vegetable tissues. In relation to the other evaluated compounds, including the dolomitic limestone and, notably, urea and calcium nitrate, these require a longer exposure period and permanence to allow interaction and activity; although also contributing to improve the micro-habitat and the provision of nutritional elements favorable to the development of microorganisms.

With the activity of the dehydrogenase enzyme, it was confirmed that there were no differences among the treatments (Duncan, $P \geq 0.05$ ) after the first application (Figure 2 and Table 3). However, in the second evaluation it was observed that, with the exception of the urea, there was an increase in the activity of the dehydrogenase in all the treatments, with variations between $16.94 \%$ and $33.53 \%$. Between the second and third evaluations it was observed that in all treatments a decrease in the activity of the dehydrogenase enzyme occurred, amounting to between $9.90 \%$ for dolomitic limestone and $72.41 \%$ for the control.

The data presented reveal that all the treatments showed very similar trends in relation to application responses. There was an increase in enzymatic activity from the first to the second application, followed by a decrease. This behavior can be explained by fact that, at the beginning of the experiment, there was a huge amount of plant material, which corresponded to the leaves under the plant's crowns. The application of different treatments, directly providing nutrients (nitrogen sources), or microorganisms, increased the microbial population, which can be undoubtedly verified by the peak in dehydrogenase activity. In fact, the highest peaks were observed in the treatments with effective microorganisms and Soil-Set $\AA+$ Compostaid $\AA$, showing that these were highly efficient in reconstituting the soil microfauna. Throughout the experiment the microbial population dwindled because there was a progressive reduction in leave mass, the substrate for microorganism development. However, in all treatments the activity remained higher when compared to the control.

It is known that enzymatic activity can be affected by the addition of microorganisms to the soil. Caire et al. (2000) obtained an increase of 30\% in dehydrogenase enzymatic activity when adding microorganisms to the soil. Benitez et al. (2000) also obtained an increase of $20 \%$ in the dehydrogenase enzymatic activity when testing the addition of dead coverage and microorganisms. Srinivas \& Raman (2002) added 10 t/ha of the organic fertilizer FYM, which is rich in microorganisms, and obtained significant increases in the activity of dehydrogenase. Nevertheless, in all these studies, the enzymatic activity was evaluated in soil samples.

According to Stroo et al. (1989), by the biological diversity of some substrates, the organisms can have a broad spectrum of extra cellular enzymes to convert into equivalent metabolites. Thus, given the favorable physical, chemical and biological aspects existent in the substrates, such as in the calcium nitrate and dolomitic limestone, the microorganisms use primarily this route, aiming to biosynthesize intermediate compounds and, thereafter, the other products that result from conversion of the organic substrate, such as vegetable tissues. Apparently this fact is part of the reason for the increased activity of the dehydrogenase enzyme, which was more evident in the evaluations and resulted in the increased population of microorganisms in the leaf plots treated with the products previously mentioned.

In all plants evaluated, symptomatic fruits were found, indicating equal availability and distribution of inoculum in all experimental plots. The levels of severity observed, determined by a grade scale (Spósito, 2003) and established

TABLE 2 - Percentage of cellulose measured in Sicilian lemon leaves after treatment for their decomposition acceleration. Rio Claro-SP, Brazil, 2004/2005

\begin{tabular}{lc}
\hline \hline Treatments & $\begin{array}{c}\text { Cellulose } \\
\text { (\% of dry matter) }\end{array}$ \\
\hline (T1) Urea & $9.26 \mathrm{~b}^{1}$ \\
(T2) Calcium Nitrate & $10.07 \mathrm{~b}$ \\
(T3) Limestone & $10.60 \mathrm{~b}$ \\
(T4) Embiotic & $6.41 \mathrm{a}$ \\
(T5) Soil-Set ${ }^{\circledR}+$ Compostaid $^{\circledR}$ & $7.20 \mathrm{a}$ \\
(T6) Control & $9.44 \mathrm{~b}$
\end{tabular}

${ }^{1}$ Means followed by the same letter are not significantly different (Duncan, $P \geq 0.05$ ). 
in terms of disease index (McKinney, 1923), revealed that all treatments were statistically different from the control (Tukey, $P \leq 0.05$ ). The disease index ranged from 1.0, as in the case of the Soil-Set ${ }^{\circledR}+$ Compostaid ${ }^{\circledR}$ treatment, and up to 2.5 in the control treatment (Table 4). The comparison of means according to Czermainski (1999) showed the same results, with the control treatment differing from the others. The residues of $\mathrm{w}$ and DI had normal distribution but did not exhibit variance homogeneity (data not presented).

Upon analysis, in the control treatment it was verified that there was a predominant symptom for hard spot, commonly originated from ascospores. These structures result mainly from citrus leaves fallen on the soil, not being produced in fruits, branches or in symptomatic leaves (Kotzé, 1988). Thus, in indirect terms it can be said that the products used contribute to accelerating the decomposition of lemon leaves, with consequences for the removal and/or reduction of training and the consequent release of ascospores.

As demonstrated by Fagan \& Goes (1999), there is a directly proportional relation between the levels of severity and percentage of fallen fruits. According to these researchers, premature fruit drop is more significant when the values of the disease index are situated at more than 3.0. Normally, these values are observed in orchards where the disease has been established for several years and shows high levels of inoculum. In this case, although the values corresponding to the levels of severity observed were of low magnitude, as mentioned by the authors, a slight presence of symptomatic fruits fallen on the soil was observed. Thus, being a relatively new orchard, and with good management conditions, the presence of premature fruit drop confirms the destructive potential of the disease, and obviously, the necessity to control the pathogen.

It was verified that, with the accelerated decomposition of fallen leaves, the levels of severity were relatively similar to each other, being consistent with the results obtained in terms of dry matter weight reduction, degradation of cellulose and activity of the dehydrogenase enzyme. Therefore, it can be concluded that the results obtained demonstrated: i. the decomposition acceleration viability of fallen citrus leaves by the use of nitrogen fertilizers, as well as products that accelerate

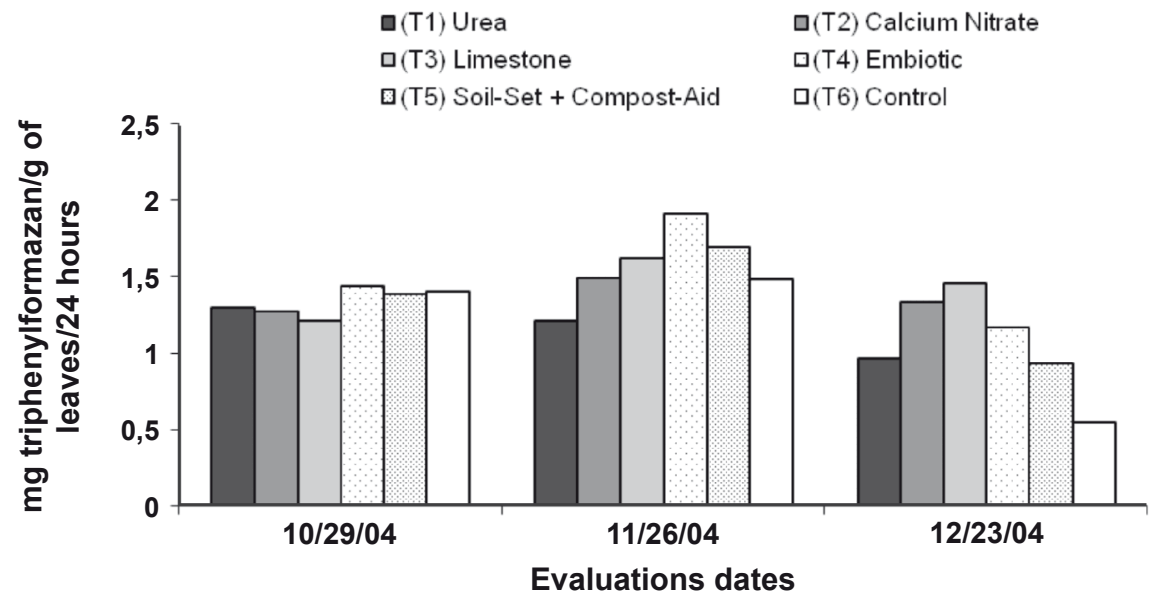

FIGURE 2 - Variation in the dehydrogenase enzyme activity over time (mg TPF $1 / \mathrm{g}$ of leaves/24 hours) evaluated in Sicilian lemon leaves. Rio Claro-SP, Brazil, 2004/2005. $\mathrm{s}$ followed by the same letter are not significantly different (Duncan, $P \geq 0.05$ ).

TABLE 3 - Dehydrogenase enzymatic activity evaluated in Sicilian lemon leaves after the decomposition acceleration treatments. Rio Claro-SP, Brazil, 2004/2005

\begin{tabular}{|c|c|c|c|}
\hline \multirow[t]{2}{*}{ Treatments } & \multicolumn{3}{|c|}{$\begin{array}{c}\text { Enzymatic activity } \\
\text { (mg TPF }{ }^{1 / g} \text { of leaves } / 24 \text { hours) }\end{array}$} \\
\hline & Sample 1 & Sample 2 & Sample 3 \\
\hline (T1) Urea & $1.295 \mathrm{a}^{1}$ & $1.210 \mathrm{a}^{1}$ & $0.966 a b^{1}$ \\
\hline (T2) Calcium Nitrate & $1.270 \mathrm{a}$ & $1.486 \mathrm{ab}$ & $1.328 \mathrm{~b}$ \\
\hline (T3) Limestone & $1.209 \mathrm{a}$ & $1.615 \mathrm{ab}$ & $1.455 \mathrm{~b}$ \\
\hline (T4) Embiotic ${ }^{\circledR}$ & $1.433 \mathrm{a}$ & $1.909 \mathrm{~b}$ & $1.158 \mathrm{ab}$ \\
\hline (T5) Soil Set ${ }^{\circledR}+$ Compostaid $^{(B)}$ & $1.382 \mathrm{a}$ & $1.685 \mathrm{ab}$ & $0.923 \mathrm{ab}$ \\
\hline (T6) Control & $1.396 \mathrm{a}$ & $1.704 \mathrm{~b}$ & $0.545 \mathrm{a}$ \\
\hline
\end{tabular}

${ }^{1}$ Means followed by the same letter are not significantly different (Tukey, $P \geq 0.05$ );

${ }^{1} \mathrm{TPF}=$ triphenylformazan. 
TABLE 4 - Effects of the treatments for decomposition acceleration of Sicilian lemon leaves from under the crown of the plants, and the levels of severity of citrus black spot, caused by Guignardia citricarpa. Rio Claro SP, Brazil, 2004/2005

\begin{tabular}{lc}
\hline \hline Treatments & Disease index \\
\hline (T1) Urea & $1,27 \mathrm{a}^{1}$ \\
(T2) Calcium Nitrate & $1,19 \mathrm{a}$ \\
(T3) Limestone & $1,13 \mathrm{a}$ \\
(T4) Embiotic & $1,10 \mathrm{a}$ \\
(T5) Soil-Set $^{\circledR}+$ Compostaid $^{\circledR}$ & $1,00 \mathrm{a}$ \\
(T6) Control & $2,47 \mathrm{~b}$
\end{tabular}

${ }^{1}$ Means followed by the same letter are not significantly different (Tukey, $P \geq 0.05$ ).

the decomposition of organic compounds, and, ii. the existence of a complementarymeasure to controlG. citricarpa. Obviously, additional studies are necessary, focusing on implementation, in terms of practicality, and economic viability.

\section{ACKNOWLEDGEMENTS}

The authors would like to thank Fundação de Amparo à Pesquisa do Estado de São Paulo - Fapesp for financial support. We would also like to thank Prof. Dr. Antonio Sérgio Ferraudo, from the Departamento de Ciência Exatas da Universidade Estadual Paulista, Campus de Jaboticabal, for his help with statistical analysis. Antonio de Goes is a fellow of Conselho Nacional de Desenvolvimento Científico e Tecnológico $-\mathrm{CNPq}$.

\section{REFERENCES}

Agrianual (2005) Anuário Agrícola Brasileiro. São Paulo SP. FNP.

Benitez E, Melgas R, Sainz H, Gomez M, Nogalez R (2000) Enzyme activities in the rhizosphere of pepper (Capsicum annuum
L.) grown with olive cake mulches. Soil Biology and Biochemistry 32:1829-1835.

Caire GZ, Cano MS, Palma RM, Mule CZ (2000) Changes in soil enzyme activities following additions of cyanobacterial biomass as exopolysaccharide. Soil Biology and Biochemistry 32:19851987.

Czermainski ABC (1999) Generalização de um índice de intensidade de infecção em experimentos de avaliação de doenças em plantas. Pesquisa Agropecuária Brasileira 34:1545-1555.

Fagan C, Goes A de (1999) Efeito da severidade da mancha preta dos frutos cítricos causada por Guignardia citricarpa na queda prematura de frutos de laranja 'Natal'. Fitopatologia Brasileira 24 (Supl.):282.

Kotzé JM (1988) Black spot. In: Whiteside JO, Garnsey SM, Timmer LW (Org.) Compendium of citrus diseases. Saint Paul MN. APS Press. pp. 10-12.

McKinney HH (1923) Influence of soil, temperature and moisture on infection of wheat seedlings by Helminthosporium sativum. Journal of Agricultural Research 26:195-217.

Nozaki MH (2007) Produção de estruturas reprodutivas e efeito do ambiente nos tipo de sintomas produzidos por Guignardia citricarpa em Citrus spp. Tese de Doutorado. Jaboticabal SP. Universidade Estadual Paulista.

Secretaria de Estado de Agricultura, Pecuária e Abastecimento de São Paulo (2008) Previsão da safra agrícola de laranja do estado de São Paulo, ano agrícola 2007/2008: 1 levantamento, maio de 2008. HTTP://ftp.sp.gov.br/ftpiea/mercado/laranja0508.pdf. Acesso em 11/09/2008.

Srinivas D, Raman S (2002) Effect of organic manures on soil dehydrogenase activity in submerged vertisol planted rice. Journal of Maharashtra Agricultural Universities 27:247-250.

Spósito MB (2003) Dinâmica temporal e espacial da mancha preta (Guignardia citricarpa) e quantificação dos danos causados à cultura dos citros. Tese de Doutorado. Piracicaba SP. ESALQ, Universidade de São Paulo.

Stroo HF, Bristow KL, Eliot LF, Papendick RI, Campbell GS (1989) Predicting rates of wheat residue decomposition. Soil Science Society of American Journal 53:91-99.

Zaman M, Di HJ, Cameron KC (1999) Gross nitrogen mineralization and nitrification rates and their relationships to enzyme activities and the soil microbial biomass in soil treated with dairy shed effluent and ammonium fertilizer at different water potentials. Biology Fertility Soils 29:178-186.

Received 18 August 2008 - Accepted 8 May 2009 - TPP 8099 Associate Editor: Francisco F. Laranjeira 